\title{
Empirical Evidence On The Valuation Of Financial Information In France
}

Melita Stephanou-Charitou, University of Nicosia, Cyprus

Adamos Vlittis, University of Nicosia, Cyprus

\begin{abstract}
We propose and examine empirically the role of financial information; namely, earnings and cash flows in France. The dataset consists of more than 1,000 French firm-year observations over a tenyear period. Regression analysis is undertaken to test the major research hypotheses. The major conclusions drawn from the empirical results are summarized as follows. First, results indicate that both earnings and cash flows are taken into consideration by French investors in their investment decisions. Second, given cash flows, results show that earnings are always very important to investors and financial analysts for investment purposes. However, results reveal that investors in France place much more attention to earnings and less attention to cash flows. In summary, the evidence provided in this study supports that indeed there are substantial differences in the way investors and financial analysts perceive financial information, such as earnings and cash flows in France. The results of this study should be of great importance to the major stakeholders, such as investors, creditors and financial analysts, especially after the latest financial scandals and collapses of giant organizations worldwide. Furthermore, these results support that fundamental analysis plays a very important role in the capital markets and it should be taken more seriously into consideration by the stakeholders for investing, credit, financing and valuation analysis purposes.
\end{abstract}

Keywords: Capital markets, Earnings, Cash flows, France, Empirical

\section{INTRODUCTION}

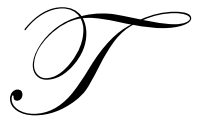

he valuation of earnings has been among the primary empirical questions raised in several capital market studies in the few decades. The value relevance of earnings has also been examined in conjunction with cash flows (Cheng and Yang; 2003: Ball et al, 2003; Bartov et al., 2001; Ball et al., 2000, among others). Empirical research provided evidence to support that earnings are more useful than cash flows in the capital markets. Existing evidence on the association of operating cash flows beyond earnings in explaining security returns has been mixed. Furthermore, to date, comparative international research on the value relevance of cash flows has been limited and inconclusive (Bartov et al, 2001).

Indeed, earnings are considered the primary variable in capital markets, especially for security valuation, in executive compensation contracts, in credit, and investment decisions (Ball et al. 2003). Although earnings are considered the dominant measure in the capital markets, the existence of information asymmetries between management and the suppliers of capital created a demand by these parties for other measures of performance, especially cash flows. Earnings can be criticized because they are affected by arbitrary allocations. Management has some discretion over the recognition of accruals. If management uses their discretion to manipulate earnings, then earnings will become a less reliable measure of performance and cash flows could be preferable. Proponents of cash flows support that cash flows are not affected by arbitrary allocations and are not manipulated by management. On the other hand, cash flows cannot be reported alone because they are influenced by timing and matching problems that cause them to be a noisy measure of firm performance (Bartov et al., 2001). Empirical research thus far provided evidence to support that earnings dominate cash flows in the marketplace. Existing evidence on the value relevance of cash flows beyond earnings has been inconclusive. The inconclusive results in prior studies, and the limited research on this issue, provide motivation for this study. 
This research study differs from prior studies in the following respects. First, it examines not only the value relevance of operating cash flows beyond earnings, but it also examines the role of cash flows in the capital markets after considering the industrial effects on the relative usefulness of operating earnings and cash flows in explaining security returns. Second, the above major research questions are examined empirically using French data (a code law country) in order to determine whether the valuation role of financial information differs in France compared to prior US results.

The present study hypothesizes that the homogeneity across firms may not hold due to firm-specific, industryspecific, and country-specific differences across firms. More specifically, it is hypothesized that the association of operating cash flows and earnings with security returns is affected by the industry the organization belongs to. Regression models will be employed to examine the value relevance of earnings and cash flows in the capital markets for a ten-year period. The aggregate data will be broken into three industries according to Standard and Poors Industrial classification. Standards and Poors classifies organizations into the following three major industrial groups: 1) manufacturing; 2) retail; and 3) services.

Statistical analysis was undertaken in this study to test the major hypotheses. A sample of 1,181 French firmyear observations was used to test the research hypotheses. The major conclusions of the empirical results are summarized as follows.

First, regarding hypothesis one which stated that earnings and cash flows are associated with stock prices in France, results indicate that both earnings and cash flows are taken into consideration by investors in their investment decisions. Second, regarding hypothesis two, which stated that earnings are valued by investors beyond cash flows and moreover, cash flows are valued by investors beyond earnings, statistical analysis revealed the following: given cash flows, earnings are always very important to investors and financial analysts for investment purposes. As far as France is concerned, results reveal that investors in that conservative country place much more attention to earnings and little or no attention to cash flows. Third, as far as hypothesis three is concerned, which states that investors place different attention to financial information, such as earnings and cash flows, depending on the industry they analyze, results of this study support this hypothesis. Specifically, results indicate that consistent with our hypothesis and expectations, the statistical results indicate that earnings and cash flow information is industry specific; that is, investors and financial analysts pay different attention to earnings and cash flows depending on the industry they analyze. Specifically, investors value more the earnings in the service industry, partly because in that industry the manipulation of earnings is the least since there exist the least accruals (i.e., depreciation, amortization, inventories, etc). As far as the cash flow information is concerned, results indicate that investors value cash flow more in the manufacturing industry. This is not surprising because in that industry, investors and financial analysts expect greater manipulation of earnings due to much higher accruals (i.e., depreciation, amortization, inventories, etc.), thus analysts pay less attention to earnings and consequently pay more attention to cash flows.

In summary, evidence provided in this study supports that there are substantial differences in the way investors and financial analysts perceive financial information, such as earnings and cash flows in France.

\section{LITERATURE REVIEW}

\subsection{Comparative Analysis of the Empirical Evidence on the Value Relevance of Earnings and Cash Flows}

In this section we provide a critical review and a comparative analysis of the empirical studies that have been undertaken regarding the value relevance of earnings and cash flows internationally. As it can be seen in the discussion that follows the majority of the studies undertaken thus far relate to the US and UK empirical evidence. Furthermore, the value relevance of cash flows has been examined more extensively only in the past two decades. Earlier studies examined mainly the value relevance of earnings.

In this section, we will discuss those empirical studies that compared and contrasted the value relevance of earnings or cash flows or both in a comparative way. 
Earlier studies by Alford et al (1993), Charitou (1997), Pope and Walker (1999) observed considerable variation in the explanatory power of earnings in explaining security returns in the countries under investigation. Regarding USA and UK results indicated that earnings are value relevant in the capital markets and that earnings in UK are more value relevant and timely than USA earnings.

Ball, Kothari and Robin (2000) and Bartov, Goldberg and Kim (2001) and Charitou et al (2000) extended prior studies and examined in more depth the value relevance of cash flows in international capital markets. In summary, results of comparative international studies indicate clearly that earnings are valued in the marketplace, but it is not clear if earnings in code or common law countries are valued more. As far as the value relevance of cash flows is concerned in different countries, evidence has been very limited. The major objective of this study is to extend prior studies by examining in more depth the value relevance of both earnings and cash flows in a code law country, namely France. Furthermore, in order to get more robust results we will use several methodologies, among those level and changes of earnings and cash flows, and industry effects. It should be stressed that in all the aforementioned studies only one of the methodologies is used and even some of them examined only earnings and not cash flows.

\section{MOTIVATION AND DEVELOPMENT OF HYPOTHESES}

Thus far the literature that relates to the value relevance of financial information (earnings and cash flows) was critically evaluated. Specifically, in this section an in depth discussion of two major issues was provided: a) the role of financial information in capital markets and b) comparative international financial reporting. As far as the first issue is concerned, an in depth critical evaluation was provided that related to i) the value relevance of earnings and cash flows, ii) the role of earnings in the capital markets, iii) the empirical evidence on the usefulness of earnings and cash flows in the marketplace, and iv) the use of contextual factors in improving the association between financial information and security returns.

Based on the critical discussion and analysis presented in this section, it is concluded that the value relevance of earnings and cash flows is still an open research question. Are earnings or cash flows valued more in Code law countries, such as France? Are earnings or cash flows valued more in the service or manufacturing or retail industries? These are some unanswered research questions in the capital markets literature. In this study we attempt to provide answers to the aforementioned questions. Specifically, this research study differs from prior studies in the following respects. First, it examines not only the value relevance of operating cash flows beyond earnings, but it also examines the role of cash flows in the capital markets after considering the industrial effects in a code law country on the relative usefulness of operating earnings and cash flows in explaining security returns. Thus far, to the best of our knowledge no other study has examined the above issues using French data. Since there are several financial reporting, economic and social differences between Anglo Saxon and Code law countries, it is expected that this study will provide new insight regarding the effect, if any of these differences, on the value relevance of earnings and cash flows.

Based on the aforementioned discussion, the following hypotheses are developed and tested:

H1: There exists a positive association between operating earnings (cash flows) and security returns in France.

H2: Operating earnings (cash flows) are associated with security returns, given operating cash flows (earnings) in France.

H3: The relative informativeness of operating earnings and cash flows is industry specific in France.

The first hypothesis tests whether there exists a positive association between operating earnings (cash flows) and security returns in France. The second hypothesis extends the first one by testing the value relevance of cash flows (earnings) beyond earnings (cash flows) in France. The objective of this hypothesis has been threefold: first to provide empirical support for the propositions made by all international standard setting bodies that both earnings and cash flows play an important role in the marketplace; second, to strengthen the evidence provided thus far regarding the value relevance of earnings and cash flows; and third, to provide evidence in a code law country regarding the value relevance of earnings and cash flows. Hypothesis three tests the value relevance of earnings and cash flows by taking into 
consideration various contextual factors, namely, industry effects. The third hypothesis predicts that the value relevance of earnings is industry specific. The methodology discussed in the next section will be used to empirically test the three research hypotheses that were motivated in this section.

\section{METHODOLOGY}

\subsection{Sources of Data}

The sample of French firms includes all public firms listed in French stock exchanges with available financial data reported by these firms through their financial reports. The French sample firms with available monthly data for security returns, and available annual data for operating earnings, operating cash flows and market value of equity for a ten year period will be included in the sample.

All firms included in these databases are categorized by industry (industry code is called Standard Industrial Classification, SIC).

\subsection{Measurement of Financial and Market Variables}

The financial and market variables to be included in the regression models are defined as follows:

- Stock Returns ( $\mathrm{R}_{\mathrm{it}}$ ): The return for security $\mathrm{i}$ in year $\mathrm{t}$ was defined as cash dividends (DIV), plus capital gains (losses), divided by the market value of equity at the beginning of the fiscal year.

$\mathrm{R}_{\mathrm{it}}=\left(\mathrm{P}_{\mathrm{t}}-\mathrm{P}_{\mathrm{t}-1}+\mathrm{DIV}_{\mathrm{t}}\right) / \mathrm{P}_{\mathrm{t}-1}$

where:

$\mathrm{P}_{\mathrm{t}}=$ security price of the firm at the end of the fiscal year $\mathrm{t}$

$\mathrm{DIV}_{\mathrm{t}}=$ Cash dividends for the year $\mathrm{t}$

Stock Returns were calculated for the 12 month period, ending three months after the fiscal year-end.

Operating Earnings (OE): Net profit before extraordinary items, discontinued operations, special and non-operating items.

Cash flow from operations (OCF): Operating earnings plus all non-cash expenses and revenues (non-current accruals) plus net changes in all working capital accounts related to operations, except for changes in cash, marketable securities, and debt in current liabilities (current accruals).

The difference between earnings (OE) and cash flow from operations (OCF) each period is equal to all operating accruals $(\mathrm{OA})$.

All independent financial variables (levels and changes of earnings and cash flows) used in the statistical models are deflated by the market value of equity of the firm $(\mathrm{P})$ at the beginning of the fiscal-year.

\subsection{The Empirical Models}

In the empirical models, the relationship between the levels and changes of earnings (OE, $\Delta \mathrm{OE}$ ) and levels and changes of cash flows (OCFO, $\triangle \mathrm{OCF}$ ) with stock returns will be tested using the following statistical models:

\subsubsection{Multivariate Regression Models}

In order to test whether a) both the levels and changes of earnings are valued in the capital markets, b) cash flows are valued in the capital markets by investors beyond earnings, and c) both the levels and changes of cash flows are 
valued by investors in the market place in France, the following full multivariate regression model will be used:

$\mathrm{RET}_{\mathrm{it}}=\mathrm{c}_{0}+\mathrm{c}_{\mathrm{i}} \mathrm{OE}+\mathrm{c}_{2} \Delta \mathrm{OE}+\mathrm{c}_{3} \mathrm{OCF}+\mathrm{c}_{4} \Delta \mathrm{OCF}+\mathrm{e}_{\mathrm{i}}$

where:

OE: Operating Earnings

$\triangle O E: \quad$ Change in operating-earnings

OCF: Operating cash flows

$\triangle O C F$ : Change in operating cash flows.

$\mathrm{R}_{\mathrm{it}}$ : $\quad$ stock return for firm i measured over a 12-month return interval ending three months after the fiscal-year-end.

\section{EMPIRICAL RESULTS}

The research hypotheses discussed earlier are tested in what follows empirically. Statistical analysis for the above datasets was conducted in this study. A critical analysis and discussion of all models tested is presented.

\subsection{Multivariate Regression Analysis Results on the Value Relevance of Earnings and Cash Flows in France}

In order to test how investors perceive simultaneously in their investment decisions on all four variables, we will include in the model both the level and changes of earnings and cash flows. The results of the value relevance of both the levels and changes of cash flows (earnings) beyond earnings (cash flows) are presented in Table 1. It is hypothesized that the coefficients of the earnings variables be positive and statistically significant. Also, the coefficients of the cash flow variables are expected to be positive and statistically significant due to the increased attention to cash flow reporting in recent years and due to the importance of cash flows in the capital markets.

Consistent with our research hypothesis, results in Table 1 indicate that the levels and changes in earnings are valued by investors beyond cash flows. All the coefficients of earnings are consistent with the expectations; i.e. positive and statistically significant. The sum of the coefficients of earnings is close to unity (as expected) in France. Specifically, the sum of the earnings coefficients $(\mathrm{c} 1+\mathrm{c} 2)$ is 1.01 in France. These results indicate that investors in France pay more attention to earnings in making investment decisions, compared to investors in the USA as provided in previous studies.

Regarding the importance of cash flows is concerned, results in Table 1 indicate that the cash flow variables are not taken into consideration for investment decisions in France. The sum of the cash flow coefficients $c_{3}+c_{4}$ are 0.013 in France. As far as the significance of the models is concerned, results indicate that the model is statistically significant as it is shown by the F-values and p-values. Specifically, the F-values of the models are 49.5 for France. In France the models are highly statistically significant at $\mathrm{p}=0.000$. As far as the explanatory importance of the model is concerned, the models' $\mathrm{R}^{2}$ is relatively high in France, and this is mainly due to the significance of earnings. Specifically, the $\mathrm{R}^{2}$ is $17.90 \%$ in France. These results indicate that French capital market participants take more into consideration the earnings information in making investment decision.

In summary, the results presented thus far do support our research hypothesis 2. Specifically, the following conclusions can be drawn by testing hypothesis 2: a) that earnings are valued by investors in France, b) earnings are valued more by French investors compared to prior studies conducted using US data, c) cash flows are not valued by French investors, given earnings, d) all models are highly statistically significant as shown by the p-value of the models, f) variability in stock prices is affected mostly in France by the variables included in the model, as it is shown by the high $\mathrm{R}^{2}(17.9 \%)$. 
Table 1

Multivariate analysis regression results for all years tested for all firms in France. MODEL WITH FOUR VARIABLES

\begin{tabular}{|c|c|c|c|c|c|c|c|c|c|c|c|}
\hline \multicolumn{12}{|c|}{ Results for the level and changes of earnings and cash flow model: RET $=\mathrm{c0}+\mathrm{c1} \mathrm{OE}+\mathrm{c2} \Delta \mathrm{OE}+\mathrm{c3} \mathrm{OCF}+\mathrm{c4} \Delta \mathrm{OCF}$} \\
\hline \begin{tabular}{|l|} 
COUNTRY \\
\end{tabular} & & Constant & OE & $\Delta \mathrm{OE}$ & OCF & $\triangle \mathrm{OCF}$ & $\mathrm{c1}+\mathrm{c} 2$ & c3+c4 & $\mathbf{N}$ & F - value & R2 adj \\
\hline FRANCE & Coefficient & $0.019 * * *$ & $0.572 *$ & $0.438^{*}$ & 0.061 & -0.048 & $1.010^{*}$ & 0.013 & 1165 & $49.5 *$ & $17.90 \%$ \\
\hline & t-statistic & $(1.693)$ & $(7.842)$ & $(6.401)$ & $(1.390)$ & $(-1.273)$ & 12.986 & 0.307 & & {$[0.000]$} & \\
\hline & VIF's & & 1.297 & 1.306 & 1.459 & 1.403 & 0.078 & 0.042 & & & \\
\hline
\end{tabular}

*, **, *** Statistically significant at a=1\%, 5\% and $10 \%$ respectively; ( ), Figures in parentheses represent t-statistic; [], Figures represent p-value

Where OE: operating earnings, $\Delta$ OE: Changes in earnings, OCF: Operating cash flows, $\Delta$ OCF: changes in Operating Cash flows; R: annual security returns. All Independent variables $(\mathrm{OE}, \Delta \mathrm{OE}, \mathrm{OCF}, \Delta \mathrm{OCF})$ are deflated by the market value of the firm at fiscal year end of the previous year.

\section{TABLE 2}

Multivariate analysis regression results by Industry for all ten years tested for all firms for France

\begin{tabular}{|c|c|c|c|c|c|c|c|c|c|c|}
\hline & & Constant & OE & $\Delta \mathrm{OE}$ & OCFc & $\Delta \mathrm{OCF}$ & & & & \\
\hline \multirow[t]{2}{*}{ COUNTRY } & INDUSTRY & $\mathbf{c}_{\mathbf{0}}$ & $\mathbf{c}_{1}$ & $\mathbf{c}_{2}$ & $\mathbf{c}_{3}$ & $\mathbf{c}_{4}$ & $\mathbf{R}^{2}$ & F-value & Model Signif & Number of firms \\
\hline & & \multicolumn{5}{|c|}{ (First line the slope coefficient, Second line the t-value) } & $\%$ & & & \\
\hline \multirow[t]{6}{*}{ FRANCE } & Manufacturing & 0.006 & 0.498 & 0.443 & 0.06 & -0.06 & 14.4 & 37.1 & $0.00 *$ & 860 \\
\hline & & $(0.42)$ & $(6.48)^{*}$ & $(5.90)^{*}$ & $(1.32)$ & $(-1.35)$ & & & & \\
\hline & Retail & 0.02 & 1.27 & 0.195 & 0.167 & -0.146 & 18.5 & 10.6 & $0.00 *$ & 170 \\
\hline & & $(0.66)$ & $(4.7)^{*}$ & $(1.06)$ & $(1.34)$ & $(-1.31)$ & & & & \\
\hline & Service & 0.06 & 1.05 & 0.89 & -0.06 & 0.11 & 13,1 & 6 & $0.00 *$ & $\underline{134}$ \\
\hline & & $(1.79) * * *$ & $(2.27)^{* *}$ & $(2.04)^{* *}$ & $(-0.32)$ & $(0.52)$ & & & & 1164 \\
\hline \multicolumn{11}{|c|}{$*, * *, * * *$ Statistically significant at $a=1 \%, 5 \%$ and $10 \%$ respectively; ( ), Figures in parentheses represent t-statistic; } \\
\hline
\end{tabular}


Even though the above results strongly support the usefulness of earnings and cash flows in investment decisions, the results should be interpreted with caution since by using aggregate data, it may be inferred that the relationship between earnings and cash flows with stock prices is homogeneous across firms. It should be noted that the assumption that investors react identically to earnings and cash flows by all firms may not be realistic. Thus, in what follows the above models are extended to take into consideration further relevant factors, such as industry effects.

\subsection{Multivariate Analysis Regression Results for Testing the Relative Valuation of Earnings and Cash Flows by Industry Effects in France}

Hypothesis 3 predicts that investors in making investment decisions pay different attention to earnings and cash flows, and this depends on the industry. The inconclusive results of previous studies, as well as the instability of the earnings and cash flow coefficients, led researchers to a further examination of this issue.

This research hypothesis predicts that operating earnings and operating cash flows are associated with security returns, but the relationship is industry specific. The results that follow extend previous studies by examining the contention made by researchers that earnings and cash flow information is industry specific. More specifically, hypothesis 3 supports that the relative valuation of the levels and changes of operating earnings and cash flows is industry specific.

Table 2 presents results for all years for France for three major industrial sectors. These industrial sectors are: a) manufacturing, b) retail, and c) service. As per Standards and Poors, firms are classified by industry by taking into consideration a Standard Industrial Classification (SIC) code. Firms with SIC code from 100 to 4999 are classified as manufacturing, firms with SIC code from 5000 to 5999 are classified as retail, and finally, firms with SIC code from 7000 to 8999 are classified as service organizations. Clearly, these type of industries have different financial characteristics. For example, manufacturing firms are more capital intensive compared to retail and service organizations. Capital intensiveness may lead to a greater need for cash flows for reinvestment purposes. Moreover, manufacturing firms have greater depreciation expenses and thus the difference between earnings and cash flows in manufacturing firms may be greater when compared to the retail and service firms. Furthermore, manufacturing and retail firms are expected to maintain higher inventory levels compared to service organizations. This difference in the inventory levels may lead to greater differences between earnings and cash flows in these two industries if there are great variations in inventory levels from year to year. For example, great increases in inventory levels in one year, assuming cash was used to manufacture or acquire this inventory, will lead to a reduction in cash flows.

Specifically results in Table 2 indicate the following. First, as hypothesized, the level of earnings variables is statistically significant in all industries. In France, the earnings coefficient is the highest in the retail industry (1.27). As far as the changes in earnings is concerned, results indicate that it is always statistically significant in the manufacturing industry. In the service and retail industry it is not significant in France. Second, as far as the role of the cash flows is concerned, results indicate that there exist industry differences that were not observed when the previous hypotheses were tested. Specifically, the level of cash flows seems to be more important to investors in the manufacturing industry. These results are consistent with our expectations since firms in the manufacturing industry have much more accruals due to higher levels of property, plant, equipment and inventory. Since these type of firms have much higher accruals, earnings can be manipulated more in these industries and thus investors and analysts pay more attention to cash flows. As far as the French results are concerned, they indicate that there is no statistically significant difference among the industries. These results are again consistent with the expectations since in code law countries there is less manipulation in financial reports. Third, as far as the model significance is concerned, in all three industries the models are highly statistically significant as it is shown by the p-values and the F-values of the model (always p-value $=0.000$ ). The F-value is shown to be the highest in the manufacturing industry, and it is shown to be the lowest in the service industry. Fourth, he lowest $\mathrm{R}^{2}$ is shown in the service industry. In France, the highest overall $R^{2}$ is shown in the retail industry. These results indicate that the variability of the stock prices is the lowest in the service industry, when taking into consideration financial information, such as earnings and cash flows.

In summary, consistent with our hypothesis and expectations, these results indicate that earnings and cash flow information is industry specific, that is investors and financial analysts pay different attention to earnings and cash flows depending on the industry they analyze. Specifically, investors value more the earnings in the service industry, partly 
because in that industry the manipulation of earnings is the least because there exist the least accruals (i.e. depreciation, amortization, inventories, etc). As far as the cash flow information is concerned, results indicate that investors value cash flow more in the manufacturing industry. This is not surprising, because as I have already argued in this industry investors and financial analysts expect greater manipulation of earnings due to much higher accruals (i.e. depreciation, amortization, inventories, etc), and thus analysts pay less attention to earnings and consequently pay more attention to cash flows.

\section{CONCLUSIONS}

In summary, the results are consistent with the three hypotheses proposed in this study. Specifically, first results indicate that earnings and cash flows are taken into consideration by investors in their investment decisions. Second, investors and financial analysts in France pay more attention to earnings than to cash flows for investing purposes. Third, results show that the value relevance of earnings and cash flows is industry specific.

Moreover, the results of this study have important practical implications as well. Since the evidence in this study supports that there are substantial differences in the way capital market participants perceive financial information, investors and credit analysts should be very cautious when making investment or credit decisions. Thus, these capital market participants should take seriously into consideration, among others, the relevant factors examined in this study.

\section{AUTHOR INFORMATION}

Dr. Melita Stephanou-Charitou is an Assistant Professor of Finance and Accounting, Division of Finance and Economics, School of Business, University of Nicosia, Cyprus.

Dr. Adamos Vlittis is an Assistant Professor of Accounting, Division of Finance and Economics, School of Business, University of Nicosia, Cyprus.

\section{REFERENCES}

1. Abad, C. J. Laffarga, C. Borbolla, A. Larran, M. Penero and N. Garrod (2000), “An evaluation of the value relevance of consolidated versus non consolidated accounting information: Evidence from quoted Spanish firms", Journal of International Financial Management and Accounting, vol 11.3, pp. 156-177.

2. Accounting Standards Board (1991), "Financial Reporting Standard No. 1, Cash Flow Statements", September, United Kingdom.

3. Alford, A., J. Jones, R. Leftwich, and M. Zmijwski (1993), “The Relative Informativeness of accounting Disclosures in Different Countries", Journal of Accounting Research, Supplement, Vol 31, pp. 183-229.

4. Ali A., and L. Hwang (2000), "Country specific factors related to financial reporting and the value relevance of accounting data”, Journal of Accounting Research, vol 38.1, pp. 1-21.

5. Ball R., S.P. Kothari and A. Robin (2000), "The effect of international institutional factors on properties of accounting earnings", Journal of Accounting and Economics 29, pp. 1-52.

6. Ball R., A. Robin and J. Wu (2003), "Incentives versus standards: Properties of accounting income in four Asian countries, and implications for acceptance of International Accounting Standards", Journal of Accounting and Economics.

7. Bartov E., S. Goldberg and M. Kim (2001), "The valuation relevance of earnings and cash flows: An international perspective", Journal of International Financial Management and Accounting, Vol 12.2.

8. Caramanolis B., L. Gardiol, A., Gibson, N Tuchschimd (1999), "Are investors sensitive to the quality and the disclosure of financial statements? ", European Finance Review, vol 3, pp. 131-159.

9. Chan K., L. Chan and N. Jegadeesh (2006), "Earnings quality and stock returns", Journal of Business, July 2006 (forthcoming).

10. Charitou, A. (1997), "The role of cash flows and accruals in explaining security returns: Evidence for the U.K", The European Accounting Review, Vol. 6:4, pp. 629-652.

11. Charitou, A., C. Clubb and A. Andreou (2000), "The Value relevance of earnings and cash flows: Empirical evidence for Japan", Journal of International Financial Management and Accounting. 
12. Cheng A. and Yang S. (2003), 'The Incremental Information Content of Earnings and Cash Flows from Operations Affected by their extremity", Journal of Business Finance and Accounting, Vol. 30 page 73.

13. Dechow, P. (1994), "Accounting Earnings and Cash Flows as measures of firm Performance. The role of accounting accruals", Journal of Accounting and Economics, 18.

14. Dumontier, P. (1998), "Accounting earnings and firm valuation: the French case", European Accounting Review, vo. 7, no. 2, pp, 163-183.

15. Dumontier P., and B. Raffournier (2002), "Accounting and Capital Markets: a survey of the European Evidence", European Accounting Review, vol 11.1, pp. 119-151.

16. Garrod, N. and M Hadi (1998), "Investor response to cash flow information", Journal of Business Finance and Accounting, Vol 25, June/July, pp. 613-630.

17. Giner B., and C. Reverte (1999), "The value relevance of earnings disaggregation provided in the Spanish profit and loss account", European Accounting Review, vol 8.4, pp. 609-629.

18. Uhrig-Homburg, M. (2005), "Cash flow shortage as an endogenous bankruptcy reason", Journal of Banking and Finance (forthcoming).

19. Vuolteenaho, T. (2002), "What drives firm level stock returns", Journal of Finance, February. 
International Business \& Economics Research Journal - March 2010

Volume 9, Number 3

NOTES 